\title{
ANALISIS DAN PERANCANGAN APLIKASI PENJADWALAN ARMADA TRAVEL MENGGUNAKAN METODE FUZZY WEIGHTED PRODUCT (FWP)
}

\author{
Bagus Wisnu Wahyanto ${ }^{1}$, Syahroni Wahyu Iriananda ${ }^{2}$ \\ baguswisnu2602@gmail.com, syahroni@widyagama.ac.id \\ Jurusan Teknik Informatika, Universitas Widyagama Malang
}

\begin{abstract}
Travel Satria Trans is a provider of transportation services, must provide the best for every customer who needs it so that travel business can continue to grow and able to compete in the business world. So is the fleet / car scheduling. The application of Fuzzy Weighted Product in the fleet / car scheduling can determine the alternative for decision makers, so that the fleet / car scheduling process can be effective and efficient and produce an objective decision. Weighted Product method is more appropriate to do assessment and ranking on the scheduling with the number of many alternatives because it is more efficient. 2) From the calculation of the priority weight with the Fuzzy Weighted Product method, the highest car with the longest delay is the third car $(0,552)$, the medium delay is Xenia car $(0,207)$, just in time is Innova car $(0,169)$ and car come Before the time runs out is a car Avanza (0.070) then obtained the fleet / car that kemungkan most experiencing delay from the scheduled schedule is the car Ertiga $(0,552)$. With these results, it can be used as an alternative in the most efficient fleet / car scheduling for Travel Satria Trans services.
\end{abstract}

Keywords: transportation service, Fuzzy Weighted Product

\section{PENDAHULUAN}

Mobil Travel Satria Trans merupakan salah satu perusahaan rental mobil dan dalam kegiatan sewa menyewa mobil yang mengutamakan pelayanan kepada pelanggannya. Guna mengutamakan pelayanan kepada pelangganya maka keakuratan dari informasi dan kemudahan mendapatkan informasi tentang data kendaraan merupakan suatu kebutuhan dari perusahaan rental mobil untuk dapat memperlihatkan efesiensi dan efektifitas usahanya. Oleh karena itu pihak manajemen hendaknya peka terhadap semua komponen informasi data kendaraan menjadi informasi yang akurat. Masalah penjadwalan ini menjadi hal yang memusingkan pihak Travel karena dengan tidak adanya sistem penjadwalan membuat mobil yang digunakan ataupun kembali tidak sesuai dengan kesepakatan. Peneliti menrapkan Fuzzy Weighted Product dapat dimanfaatkan untuk optimasi sistem karena ini sesuai dengan kriteria penjadwalan efisien. Dengan dibuatnya sistem penjadwalan penggunaan mobil dan pengembalian dengan menggunakan metode yang tepat, diharapkan akan mampu membantu Travel Satria Trans dalam mengatur jadwal dengan lebih cepat dan akurat tanpa terjadi bentrok jadwal berdasarkan parameter yang terkait.

\section{TINJAUAN PUSTAKA}

Penjadwalan secara umum dapat diartikan seperti "schedulling is the allocation of resources overtime to perform of risk", yang artinya penjadwalan adalah pengalokasian sumber daya yang terbatas untuk mengerjakan sejumlah pekerjaan. Permasalahan muncul apabila pada tahap operasi tertentu beberapa atau seluruh pekerjaan itu membutuhkan stasiun kerja yang sama. Dengan dilakukannya pengukuran pekerjaan ini unit-unit produksi dapat dimanfaatkan secara optimum. Pemanfaatan ini antara lain dilakukan dengan jalan meningkatkan utilitas unit-unit produksi melalui usaha mereduksi waktu menganggur (idle) dari unit-unit yang bersangkutan. Pemanfaatan lainnya dapat juga dilakukan 
dengan cara meminimumkan work in process (WIP) melalui reduksi terhadap waktu rata-rata pekerjaan yang menunggu dalam baris antrian pada unit-unit produksi[1]. Penjadwalan (scheduling) didefinisikan sebagai proses pengalokasian sumber untuk memilih sekumpulan tugas dalam jangka waktu tertentu. Secara rinci dapat dijabarkan bahwa penjadwalan merupakan sebuah fungsi pengambilan keputusan, yaitu dalam menentukan jadwal yang paling tepat atau merupakan sebuah teori yang berisis kumpulan prinsip, model, teknik dalam pengambilan keputusan. Penjadwalan produksi didefenisikan sebagai pengaturan urutan kerja serta pengalokasian sumber baik waktu, fasilitas untuk setiap operasi yang harus diselesaikan. Tujuan penjadwalan adalah sebagai berikut:

1. Meningkatkan penggunaan sumber daya atau mengurangi waktu tunggunya.

2. Mengurangi persedian barang setengah jadi atau mengurangi sejumlah pekerjaan yang menunngu dalam antrian ketika sumber daya yang ada masih mengerjakan yang lain.

3. Mengurangi beberapa kelambatan pada pekerjaan yang mempunyai batas waktu penyelesaian (due date) sehingga akan meminimasi penalty cost (biaya kelambatan).

4. Membantu pengambilan keputusan mengenai perencanaan kapasitas pabrik dan jenis kapasitas yang dibutuhkan sehingga penambahan biaya yang mahal dapat dihindarkan

5. Meminimasi rata-rata waktu proses dalam suatu sistem.

6. Memperbaiki keakuratan status informasi pekerjaan.

7. Mengurangi set up times.

\section{A. Teori Fuzzy}

Fuzzy adalah metodologi sistem kontrol pemecahan masalah, yang cocok untuk diimplementasikan pada sistem, mulai dari sistem yang sederhana, sistem kecil, embedded system, jaringan PC, multichannel atau workstation berbasis akuisisi data, dan sistem kontrol. Metodologi ini dapat diterapkan pada perangkat keras, perangkat lunak, atau kombinasi keduanya. Dalam logika klasik dinyatakan bahwa segala sesuatu bersifat biner, yang artinya adalah hanya mempunyai dua kemungkinan, "Ya atau Tidak", "Benar atau Salah", "Baik atau Buruk", dan lainlain. Oleh karena itu, semua ini dapat mempunyai nilai keanggotaan 0 atau 1. Akan tetapi, dalam logika fuzzy kemungkinan nilai keanggotaan berada diantara 0 dan 1 . Artinya, bisa saja suatu keadaan mempunyai dua nilai "Ya dan Tidak", "Benar dan Salah", "Baik dan Buruk" secara bersamaan, namun besar nilainya tergantung pada bobot keanggotaan yang dimilikinya[3]. Logika fuzzy adalah: "Sebuah metodologi berhitung dengan variabel kata-kata (linguistic variable) sebagai pengganti berhitung dengan bilangan. Kata-kata digunakan dalam fuzzy logic memang tidak sepresisi bilangan, namun katakata jauh lebih dekat dengan intuisi manusia". Mengenai logika fuzzy pada dasarnya tidak semua keputusan dijelaskan dengan 0 atau 1, namun ada kondisi diantara keduanya, daerah diantara keduanya inilah yang disebut dengan fuzzy atau tersamar. Proses fuzzy inference dapat dibagi dalam lima bagian, yaitu:

\$Fuzzyfikasi Input : FIS mengambil masukanmasukan dan menentukan derajat keanggotaannya dalam semua fuzzy set.

\$ Operasi logika fuzzy :Hasil akhir dari operasi ini adalah derajat kebenaran antecedent yang berupa bilangan tunggal.

\# Implikasi :Merupakan proses mendapatkan consequent atau keluaran sebuah IF-THEN rule berdasarkan derajat kebenaran antacedent. Proses ini menggunakan mengambil nilai MIN/terkecil dari dua bilangan : Hasil operasi fuzzy logic OR dan fuzzy set banyak.

* Agregasi: Yaitu proses mengkombinasikan keluaran semua IF-THEN rule menjadi sebuah fuzzy set tunggal. Pada dasarnya agregasi adalah operasi fuzzy logic OR dengan masukannya adalah semua fuzzy set.

\$Defuzzyfikasi : Keluaran dari defuzzyfikasi adalah sebuah bilangan tunggal, cara mendapatkannya ada beberapa versi, yaitu centroid, bisector, middle of maximum, largest of maximum dan smallest of maximum Fuzzy Model Sugeno merupakan varian dari model Mamdani

\section{B. Himpunan Fuzzy}

Ada beberapa hal yang perlu diketahui dalam memahami sistem fuzzy, yaitu;[4]

1. Variabel fuzzy

Merupakan variabel yang hendak dibahas dalam suatu sistem fuzzy. Contoh: umur, temperatur, permintaan, dsb. 


\section{Himpunan fuzzy}

Himpunan fuzzy merupakan suatu grup yang mewakili suatu kondisi atau keadaan tertentu dalam suatu variabel fuzzy.

3. Semesta Pembicaraan

Semesta pembicaraan adalah keseluruhan nilai yang diperbolehkan untuk dioperasikan dalam suatu variabel fuzzy. Semesta pembicaraan merupakan himpunan bilangan real yang senantiasa naik (bertambah) secara monoton dari kiri ke kanan. Nilai semesta pembicaraan dapat berupa bilangan positif maupun negatif. Adakalanya nilai semesta pembicaraan ini tidak dibatasi batas atasnya.

4. Domain

Domain himpunan fuzzy adalah keseluruhan nilai yang diijinkan dalam semesta pembicaraan dan boleh dioperasikan dalam suatu himpunan fuzzy. Seperti halnya semesta pembicaraan, domain merupakan himpunan bilangan real yang senantiasa naik (bertambah) secara monoton dari kiri ke kanan. Nilai domain dapat berupa bilangan positif maupun negatif. Perolehan Data beserta rentang nilai. Sebagian data diatas dipergunakan sebagai variabel masukan

\section{Teori WP (Weighted Product)}

Atribut yang bersangkutan. Berikut ini adalah Metode WP menggunakan perkalian untuk menghubungkan rating atribut, dimana rating setiap atribut harus dipangkatkan dulu dengan bobot atribut yang bersangkutan. Proses ini sama halnya dengan proses normalisasi [5].

Metode WP merupakan salah satu metode yang di gunakan untuk masalah keputusan multi attribut decision making (MADM). Multiple Attribute Decision Making (MADM) adalah suatu metode yang digunakan untuk mencari alternatif optimal dari sejumlah alternatif dengan kriteria tertentu. Inti dari MADM adalah menentukan nilai bobot untuk setiap atribut, kemudian dilanjutkan dengan proses perankingan yang akan menyeleksi alternatif yang sudah diberikan. Dari penjelasan diatas dapat disimpulkan bahwa Metode Weighted Product merupakan salah satu metode penyelesaian yang ditawarkan untuk menyelesaikan masalah Multi Attribute Decision Making (MADM). Metode Weighted Product juga disebut analisis berdimensi karena struktur matematikanya menghilangkan satuan ukuran, metode Weighted Product merupakan himpunan berhingga dari alternatif keputusan yang dijelaskan dalam beberapa hal kriteria keputusan. Jadi metode ini tidak perlu dinormalisasikan. Metode Weighted Product menggunakan perkalian untuk menghubungkan rating atribut, dimana rating setiap atribut harus dipangkatkan dulu dengan bobot konsep dari metode WP :[6]

1) Untuk menentukan preferensi Ai dapat dilihat persamaan berikut ini :

$$
S_{i}=\prod_{j=1}^{n} x_{i j} w_{j}
$$

Dengan $\mathrm{i}=1,2, \ldots, \mathrm{m}$ dimana $\Sigma w j=1 . w j$ adalah pangkat bernilai positif untuk dari atribut keuntungan, dan bernilai negatif dari atribut biaya.

2) Setelah Menentukan jarak Ai kemudian langkah selanjutnya menentukan preferensi untuk setiap alternative

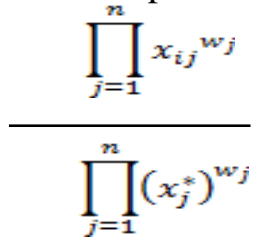

$$
\begin{aligned}
& \text { Dengan } \mathrm{i}=1,2, \ldots, \mathrm{m} \\
& =\text { preferensi untuk setiap alternative } \\
& =\text { bobot dari criteria } \\
& \text { Xij = Nilai variable dari alternative pada } \\
& \text { setiap atribut } \mathrm{n}=\text { Banyaknya kriteria } \mathrm{i}= \\
& \text { Nilai Alternatif } \\
& \mathrm{j}=\text { Nilai kriteria } \\
& * \text { = Banyaknya kriteria yang telah dinilai } \\
& \text { pada vector } \mathrm{S}
\end{aligned}
$$

\section{ANALISIS DAN PERANCANGAN SISTEM}

\section{A. Prosedur Penelitian}

Tahapan-tahapan prosedur penelitian yang dilakukan adalah :

1. Pemahaman komprehensif tentang impelementasi metode Fuzzy Weighted Product dalam Sistem Pendukung Keputusan. yaitu dengan membaca literatur-literatur yang berhubungan dengan penelitian

2. Menentukan tujuan permasalahan, mendefinisikan kriteria dan subkriteria faktorfaktor yang menentukan dan berpengaruh dalam proses penjadwalan mobil yang paling tepat dan efisien.

3. Dilakukan dengan wawancara pada pihak yang terkait dengan pihak manajemen travel dan kuesioner dibagikan kepada para pimpinan/ 
pengambil keputusan untuk mengetahui tingkat kepentingan/presepsi mereka terhadap kriteria dalam penjadwalan mobil berdasarkan parameter/ kriteria yang sudah ditetapkan. Kriteria yang akan dijadikan parameter ada 4 (empat), dapat dilihat dalam tabel 3.1. berikut ini :

Tabel 3.1 : Kriteria Penilaian

\begin{tabular}{|l|l|l|}
\hline Kode & Kriteria & Definisi \\
\hline C1 & Harga Mobil & $\begin{array}{l}\text { besar harga beli mobil } \\
\text { (cost) }\end{array}$ \\
\hline C2 & $\begin{array}{l}\text { Ketepakan } \\
\text { Waktu }\end{array}$ & besar waku yang diberi \\
\hline C3 & Jarak Tempuh & $\begin{array}{l}\text { Besar jarak tempuh } \\
\text { yang di lakukan }\end{array}$ \\
\hline C4 & Hari & $\begin{array}{l}\text { besarnya hari yang } \\
\text { dibutukan }\end{array}$ \\
\hline
\end{tabular}

Langkah selanjutnya adalah melakukan penilaian kriteria dan alternatif melalui perbandingan berpasangan. Untuk berbagai persoalan skala 1 sampai 9 adalah skala terbaik dalam mengekspresikan pendapat. Dapat dilihat pada tabel 3.2 berikut ini :

Tabel 3.2 : Skala Perbandingan Berpasangan

\begin{tabular}{|c|l|}
\hline $\begin{array}{c}\text { Intens } \\
\text { Kepentingan }\end{array}$ & \multicolumn{1}{c|}{ Keterangan } \\
\hline 1 & Kedua elemen sama pentingnya \\
\hline 3 & $\begin{array}{l}\text { 3 Elemen yang satu sedikit lebih } \\
\text { penting daripada elemen yang } \\
\text { lainnya }\end{array}$ \\
\hline 5 & $\begin{array}{l}\text { 5 Elemen yang satu lebih } \\
\text { penting daripada yang lainnya }\end{array}$ \\
\hline 7 & $\begin{array}{l}\text { Satu elemen mutlak lebih } \\
\text { penting daripada elemen lainnya }\end{array}$ \\
\hline 9 & $\begin{array}{l}\text { Satu elemen sangat mutlak } \\
\text { penting daripada elemen lainnya }\end{array}$ \\
\hline $2,4,6,8$ & $\begin{array}{l}\text { Nilai-nilai antara dua nilai } \\
\text { pertimbangan-pertimbangan } \\
\text { yang berdekatan }\end{array}$ \\
\hline
\end{tabular}

\section{B. Alur Penelitian}

Alur Penelitian ini berisi tentang bagaimana prosedur-prosedur yang berjalan pada perancangan sistem ini. Dalam perancangan flowchart ini peneliti akan menjelaskan alur sistem yang berjalan yaitu sistem yang dirancang untuk analisis metode fuzzy Weighted Product, sebagai berikut :

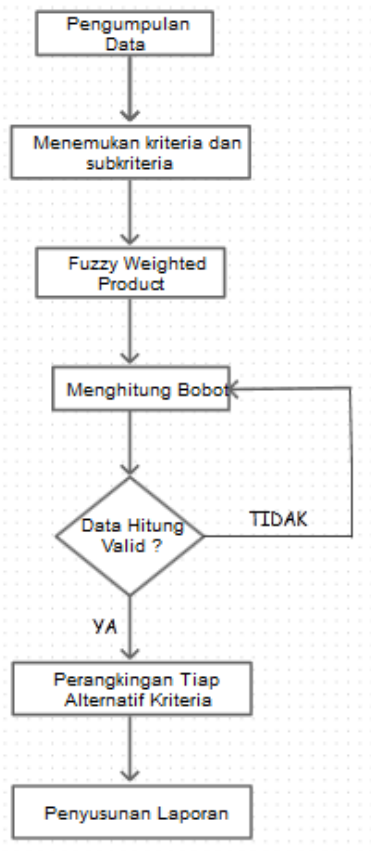

Gambar 1. Alur Penelitian

\section{Diagram Konteks}

Berikut ini adalah diagram konteks travel satria Trans dapat dilihat pada gambar

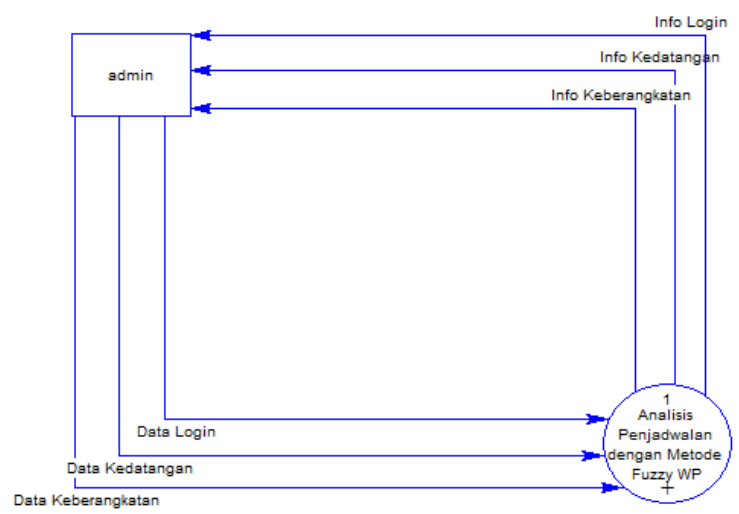

Gambar 2. Diagam Konteks 


\section{DFD (Data Flow Diagram)}

Data Flow Diagram (DFD) level 0 menggambarkan sistem yang direncanakan, sebagai landasan teori dalam mengembangakan sistem lebih lanjut. DFD level 0 Travel ini dapat dilihat pada gambar berikut

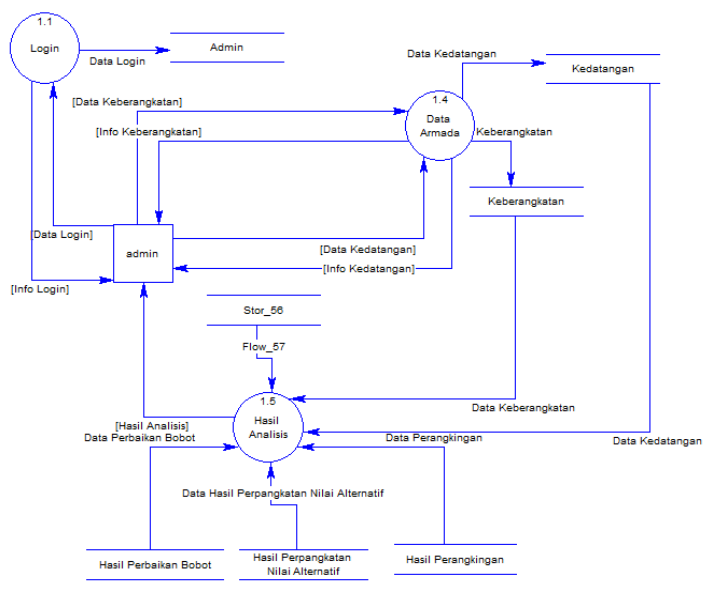

Gambar 3. DFD (Data Flow Diagram) level 0

\section{E. ERD (Entity Relationship Diagram)}

Model basis data yang digunakan adalah basis data relasional, dimana setiap entitas saling memiliki hubungan dengan entitas lain. Entitas adalah kesatuan luar yang memberikan pengaruh terhadap sistem. Berikut ini adalah diagram hubungan atara entitas atau ERD pada sistem dapat dilihat pada gambar 4 :

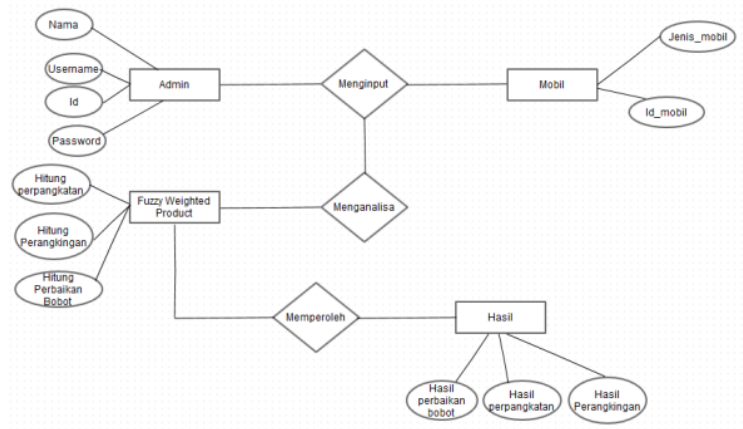

Gambar 4. ERD (Entity Relationship Diagram)

HASIL DAN PEMBAHASAN

Analisis Fuzzy Weighted Product

1. Rating Kecocokan Setiap Alternatif Kriteria

Dalam perhitungan bobot kriteria dengan metode weighted product. langkah pertama adalah menghitung tingkat kepentingan perbandingan berpasangan dari : masing-masing kriteria yaitu : Harga Mobil (C1), Ketepatan Waktu (C2), Jarak Tempuh (C3), Hari (C4). Data tingkat kepentingan perbandingan berpasangan antar kriteria ditunjukkan pada Tabel berikut ini :

Tabel 4.1 Rating Kecocokan Setiap Alternatif Kriteria

\begin{tabular}{|c|c|c|c|c|}
\hline Altematif & C1 & C2 & C3 & C4 \\
\hline Ertiga & 240 & 5 & 258 & 2 \\
\hline Xenia & 199 & 5 & 130 & 1 \\
\hline Innova & 276 & 5 & 475 & 5 \\
\hline Avanza & 201 & 5 & 345 & 3 \\
\hline
\end{tabular}

\section{Variabel Linguistik}

Selanjutnya diberikan vektor bobot preferensi pakar menggunakan bentuk linguistic, bobot yang diberikan sebagai berikut bobot yang diberikan dapat dilihat pada table 4.2.:

Tabel 4.2. Variabel Linguistik

\begin{tabular}{|c|c|}
\hline $\begin{array}{c}\text { Varuable } \\
\text { Linguistik }\end{array}$ & Bilangan Fuzzy \\
\hline Sangat Tinggi & $(7,9,9)$ \\
\hline Tinggi & $(5,7,9)$ \\
\hline Sedang & $(3,5,7)$ \\
\hline Rendah & $(1,3,5)$ \\
\hline Sangat Rendah & $(0,1,3)$ \\
\hline
\end{tabular}

\section{Hasil Perbaikan Bobot}

Setelah itu dengan menggunakan metode WP dilakukan perbaikan bobot dapat dilihat pada tabel 4.3. :

Tabel 4.3. Hasil Perbaikan Bobot

\begin{tabular}{|c|c|}
\hline Perbaikan Bobot & Hasil Perbaikan Bobot \\
\hline W1 & 0,236 \\
\hline W2 & 0,184 \\
\hline W3 & 0,131 \\
\hline W4 & 0,078 \\
\hline
\end{tabular}

\section{Hasil Pepangkatan Nilai Alternatif}

Selanjutnya menghitung nilai vektor $\mathrm{S}$, berikut hasil nilai vector $\mathrm{S}$ dapat dilihat pada tabel 4.4:

Tabel 4.4 Hasil Perpangkatan Nilai Alternatif

\begin{tabular}{|c|c|}
\hline $\mathrm{Si}$ & Nilai Si \\
\hline $\mathrm{S} 1$ & 23,213 \\
\hline $\mathrm{S} 2$ & $\mathbf{8 , 7 1 2}$ \\
\hline $\mathrm{S3}$ & 7,128 \\
\hline $\mathrm{S} 4$ & 2,941 \\
\hline
\end{tabular}


5. Hasil Hasil Perhitungan Perangkingan

Kemudian dilakukan proses perangkingan nilai vektor $\mathrm{V}$, hasil dari perhitungan perangkingan

nilai vektor $\mathrm{V}$ dapat dilihat pada tabel 4.5 :

Tabel 4.5. hasil perhitungan perangkingan

\begin{tabular}{|c|c|}
\hline Vi & Nilai V \\
\hline VI & 0,552 \\
\hline V2 & 0,207 \\
\hline V3 & 0,169 \\
\hline V4 & 0,070 \\
\hline
\end{tabular}

\section{Hasil Perangkingan Alternatif}

Kemudian dilakukan perangkingan dari alternative yang ditelah ditentukan, hasil perangkingan dapat dilihat pada tabel 4.6 :

Tabel 4.6. Hasil Perangkingan Alternatif

\begin{tabular}{|c|c|c|}
\hline Alternatif & Nilai Preferensi & Ranking \\
\hline Ertiga & 0,552 & 4 \\
\hline Xenia & 0,207 & 3 \\
\hline Innova & 0,169 & 2 \\
\hline Avanza & 0,070 & 1 \\
\hline
\end{tabular}

Dengan hasil tersebut di atas bahwa berdasarkan fitur yang diberikan, maka mobil yang paling tinggi mengalami keterlambatan paling lama adalah mobil ertiga $(0,552)$, mengalami keterlambatan sedang adalah mobil Xenia $(0,207)$, tepat pada waktunya adalah mobil Innova $(0,169)$ dan mobil datang sebelum waktunya habis adalah mobil Avanza $(0,070)$.

\section{PENUTUP}

\section{A. Kesimpulan}

Berdasarkan hasil penelitian yang dilakukan pada Travel Satria Trans dapat di tarik kesimpulan yaitu:

1. Metode Weighted Product lebih tepat untuk melakukan penilaian dan perangkingan pada penjadwalan dengan jumlah alternative yang banyak karena lebih efisien .

2. Dari hasil perhitungan bobot prioritas dengan metode Fuzzy Weighted Product maka mobil yang paling tinggi mengalami keterlambatan paling lama adalah mobil ertiga $(0,552)$, mengalami keterlambatan sedang adalah mobil Xenia $(0,207)$, tepat pada waktunya adalah mobil Innova $(0,169)$ dan mobil datang sebelum waktunya habis adalah mobil Avanza (0, 070)

\section{B. Saran}

Berdasarkan hasil kesimpulan tentang Analisis Metode Fuzzy Weighted Product untuk penjadwalan mobil pada Travel Trans Satria, maka saran yang dapat diberikan dalam meningkatkan sistem penjadwalan yaitu:

Lebih teratur dalam menjadwal keluar dan masuknya armada yang akan di gunakan sehingga dapat tahu armada mana yang akan digunakan dan armada mana yang seharunya kembali sesuai masa peminjaman dan juga costumer lain yang akan meminjam tahu armada mana yang akan digunakan.

\section{REFERENSI}

Masudin , Utama , \& Susastro. (2014). Jurnal Ilmiah Teknik Industri.

Mangngenre, Rapi, \& Flannery. (2014). Penjadwalan Produksi Dengan Metode Branch And Bound Pada Pt. Xyz.

Sukandy, Basuki, \& Puspasari. (2017). Penerapan Metode Fuzzy Mamdani Untuk Memprediksi Jumlah Produksi Minyak Sawit Berdasarkan Data.

Puspita \& Yulianti. (2016). Perancangan Sistem Peramalan Cuaca Berbasis Logika Fuzzy.

Siregar (2017). Implementasi Weight Product Model (Wpm) Dalam Menentukan Pemilihan Sepeda Motor Sport Berbasis Spk. Kumpulan jurnaL Ilmu Komputer (KLIK).

Distriawan, \& Rizqa. (2015). Implementasi Algoritma Weighted Product Dalam Menentukan Penjadwalan Dosen Di Universitas Dian Nuswantoro. 